\title{
Donne's "La Corona" and Christ's Mediatorial Office
}

\author{
R. R. DUBINSKI
}

$\mathrm{B}_{\mathrm{y}}$ pointing out the affinities between "La Corona" and certain traditional meditative practives, studies by Louis Martz and Helen Gardner have provided important contexts for understanding the poem's structure and organization. Martz contends that the poem "is a complex synthesis of methods and materials from both religious and profane poetry, from the liturgy of the Church, and from all the various ways of meditating on the life of Christ," but the fundamental impulse and outline of the sequence, he emphasizes, is found in the Catholic meditations of the corona. ${ }^{1}$ Martz draws analogies between "La Corona" and Jesuit treatises (in particular one by Sabin Chambers) to show how the meditations of the corona may have exerted a very strong influence on the construction, divisions, and general procedure of Donne's sequence. ${ }^{2}$ Helen Gardner argues that the sonnets are inspired by liturgical prayer and praise, especially the meditation on the Fifteen Mysteries of the Rosary adapted by Donne to a meditation on the life of Christ. ${ }^{3}$

Both Martz and Gardner make it clear that "La Corona" has a strong affinity with the long-standing practice of organized meditations on the life of Christ. Both also notice how Donne's poem is characterized by a mixture of Catholic and Protestant emphases. Gardner points out one Catholic emphasis: "It is doubtful whether Donne felt there was anything particularly Catholic in concentrating on the Mysteries of Faith, or in addressing his second and third sonnets to the Blessed Virgin, or in apostrophizing St. Joseph in his fourth; but it is also doubtful whether anyone who had been brought up as a Protestant would have done so." Martz explains that though Donne's sequence is influenced by the Catholic tradition of the corona, it is "addressed to Christ, and the life of the Virgin is very carefully subordinated; this is what we should expect in an Anglican adaptation of the corona." Another Protestant characteristic of the peom which neither Gardner nor Martz notices is Donne's exploration of Christ's three-fold mediatorial office.

In her study of Milton's Paradise Regained, Barbara Lewalski has 
cited several theologians to show that the term "office" in reference to Christ's mediatorial functions still had precise and widely accepted theological meanings and implications in the seventeenth century. Both Catholic and Protestant theologians were in general agreement, she points out, about the duties entailed by each of its functions, and the prefiguration of each of these functions by certain Old Testament types. $^{6}$ Catholic theologians (following St. Augustine) most commonly defined Christ's mediatorial office as incorporating the two-fold function of priest and king. Post-Tridentine catechisms such as Cardinal Bellarmine's normally included only these two: "This name of Iesus signifieth a Sauiour, \& Christ, which is his surname, signifieth high Priest, and King of al Kings." " Protestant catechisms, on the other hand, regularly favoured the three-fold office of prophet, priest and king because it gave due exaltation to Christ's preaching and teaching role. The catechisms of Alexander Nowell and Thomas Becon, for instance, explain that the Greek name Christ is a translation of the Hebrew Messiah, the anointed one, which means that Christ is the sovereign king, priest and prophet. ${ }^{8}$ Although Catholic writers give greater emphasis to his priestly role, it would not be accurate to suggest that they never refer to Christ's prophetic role. On the other hand, Protestant writers give the prophetic role more prominence and rarely fail to include it in their definition of the offices of Christ.

The characteristic Protestant division of Christ's three-fold office is crisply defined by Milton in his Christian Doctrine (Book I, Chapter XV):

His prophetic function is to educate his Church in heavenly truth and to teach the whole will of his Father .... His prophetic function has two parts, one external and one internal. The first is the revelation of divine truth, the second the illumination of the mind.

The priestly function is that in accordance with which Christ once offered himself to God the Father as a sacrifice for sinners, and has always made, and still continues to make intercession for us.

The kingly function means that Christ, having been made a king by God the Father, rules and preserves, principally by internal law and spiritual power, the Church which he has bought for himself, and conquers and crushes his enemies ... Christ's kingdom is called the kingdom of grace and the kingdom of glory. The kingdom of grace is also the kingdom of heaven which is said to be at hand in Matt. iii. 2. The kingdom of glory is the kingdom which will be shown more clearly at Christ's second coming. ${ }^{9}$

Donne shows a precisely similar understanding of Christ's three-fold office in a sermon he preached at St. Paul's on Christmas Day, 1621. Preaching on John 1, 8 ("He was not that light, but was sent to bear witnesse of that light"), Donne explains that "the second part of the Chapter layeth downe the Office of Christ, his Propheticall, his Priestly. 
his Royall Office." The office of a prophet, continues Donne, consists "in three several exercises, to manifest things past, to foretell things to come, and to expound things present." His second office, his priesthood, is "expressed in the 36. verse, Beholde the Lambe of God; for, in this, he was our Priest, that he was our Sacrifice; he was our Priest, in that he offered himselfe for our sinnes." Lastly, says Donne, "his Royall Office was the most naturall to him of all the rest .... But his Title to be King, was naturall, by descent, he was of the bloud Royall, and the nearest in succession; so that he, and onely he, had, De Jure, all the three unctions upon him." 10

It seems clear, then, that in this sermon Donne reveals the characteristic Protestant emphasis in his definition of Christ's three-fold office. I would suggest that in "La Corona" this same three-fold office has an integral place in Donne's meditation on the life of Christ. After the opening sonnet which serves both as an invocation and introduction, Donne focusses on the mystery of the incarnation in the next two sonnets - "Annunciation" and "Nativitie."11 Brief allusion is made to Christ's predestined role as priest, but the chief concern of these sonnets is the poet's astonishment at the "Immensity cloysterd" in Mary's womb. It is in the fourth sonnet, "Temple," that Donne begins to direct his attention to Christ's three-fold mediatorial office.

The "Temple" sonnet has caused critics some interpretive difficulty. Helen Gardner says that some readers "might well wonder why Donne should devote one sonnet of his seven to the Finding in the Temple, and omit all reference to the events of the Ministry, except for a brief reference to miracles." She suggests that Donne was guided by meditations on the Fifteen Mysteries of the Rosary, "and reference to them explains at once why Donne would find it natural to pass directly from the Finding in the Temple to the events of Holy Week." ${ }^{12}$ A. B. Chambers is not completely satisfied with this explanation. He can readily account for five of the sonnets (excluding the introductory one) as of critical importance to a summary of the life of Christ, but complains that there is no apparent reason for the intrusion of the sonnet which deals with the story of Jesus and the Doctors. ${ }^{13}$ Chambers, seeking to find a solution to the problem by searching in Biblical commentary for an explanation of the significance of the Temple episode, assembles evidence to suggest that the "subject matter of the fourth sonnet looks back to the human frailty of the birth of Jesus, signifies the first manifestation of his divinity, marks his entrance into the ministry, and forecasts the end for which he came." 14 Chambers has perhaps made the sonnet bear a heavier freight of interpretation than is justified, but with one aspect of his interpretation I think there can be no disagreement. What this episode clearly dramatizes is an anticipation of Christ's 
prophetic and teaching role that will be completely fulfilled in his public ministry. In the sermon quoted above, Donne points out that the office of prophet consists "in three severall exercises, to manifest things past, to foretell things to come, and to expound things present." In the sonnet, Donne explores the traditional paradox of the Verbum infans and marvels at the knowledge of the young Jesus:

The Word but lately could not speake, and loe It sodenly speakes wonders, whence comes it, That all which was, and all which should be writ, A shallow seeming child, should deeply know?

These lines demonstrate that what Donne is celebrating in the "Temple" is Christ's first public manifestation of his office as prophet. As such, the sonnet has an integral place in the sequence because in this episode Christ first begins to fulfill his Father's business, or as Donne says, "But as for one which hath a longe taske, 'tis good, / With the Sunne to beginne his businesse." 15 Chronologically in the life of Christ, the office of prophet precedes those of priest and king, and Donne appropriately chooses the Finding in the Temple as the logical place to begin his meditation on Christ's three-fold mediatorial office.

There can be no difficulty in seeing the fifth and sixth sonnets "Crucyfying" and "Resurrection" - as together focussing on Christ's role as priest, the perfect sacrifice for sinful man. And as a result of Christ's conquest over sin and death, the resurrection of the body is promised for the "last, and everlasting day." At the end of "Resurrection," the poet longs for the universal awakening from the long sleep. In "Ascention," he imagines the coming of the "last and everlasting day" and joyfully participates in the procession of saints as they march into heaven led by their king and saviour. The focus of this glorious scene, thus, is on Christ's role as king, the sovereign of the body of the faithful. As Barbara Lewalski points out, Christ's kingly role is begun on earth, but is more perfectly realized at Christ's ascension and restoration to his Father's right hand. ${ }^{16}$ Donne chooses to centre his meditation not on Christ's first ascension to heaven, but on the apocalyptic moment, when Christ the King in the company of his saints will reascend to heaven and take up eternal residence at the right hand of his Father.

This brings us then to the concluding sestet of the poem, where Donne intones his ritualistic triple invocation to Christ:

O strong Ramme, which hast batter'd heaven for mee, Mild lambe, which with thy blood, hast mark'd the path;

Bright torch, which shin'st, that I the way may see,

Oh, with thine owne blood quench thine owne just wrath,

And if thy holy Spirit, my Muse did raise,

Deigne at my hands this crowne of prayer and praise. 
As a conclusion to his meditation on Christ's mediatorial office, Donne fittingly offers praise to Christ for each of his three roles - King, Prophet and Priest. As warrior-king overcoming the enemies of his people and leading them to heaven, Christ is invoked as the "strong Ramme."17 In offering himself as a perfect satisfaction for his people's sinfulness, Christ is both priest and victim, and is invoked as the "Mild lambe." And as the light of truth that shows the way, he is invoked as the "Bright torch."18

It seems evident, then, that in "La Corona" Donne makes integral use of the commonplace Protestant emphasis on Christ's three-fold mediatorial office. This context not only clarifies the significance of the climactic triple invocation at the end of the poem, and throws light on the structure of the poem, but also provides additional evidence of the way Donne modified Catholic traditions of meditation in a Protestant direction.

University of Waterloo

\section{Notes}

1 Louis Martz, The Poetry of Meditation (New Haven, 1954), p. 108.

2 Hartz, p. 110.

3 Helen Gardner, ed., John Donne: The Divine Poems (Oxford, 1952), p. xxii.

4 Gardner, p. xxii.

5 Martz, p. 107.

6 Barbara Lewalski, Milton's Brief Epic (London, 1966), pp. 1982-83.

7 Cardinal Bellarmine, An Ample Declaration of the Christion Doctrine, Trans. in part

(Doway, 1604), p. 23. See also Peter Canisius, A Summe of Christian Doctrine, trans. in part by Henry Garnet (1592-96), p. 10.

8 A Catechism written in Latin by Alexander Nowell Dean of St. Paul's: Together with The Same Catechism Translated into English by Thomas Norton, ed. G. E. Corrie (Cambridge, The Parker Society, 1853), XXXII, 152. The Catechism of Thomas Becon, S.T.P., ed. Rev. John Ayre (Cambridge, the Parker Society, 1844), III, 22.

9 Maurice Kelley, ed., Complete Prose Works of John Milton (New Haven, 1973), VI, 432-37. Kelley points out that the tripartite division of Christ's office is a commonplace of Reformation dogmatics (p. 432).

10 George Potter and Evelyn Simpson, edd., The Sermons of John Donne (Berkeley, 1957), III, 349-50.

11 All citations from "La Corona" will be from the edition of Gardner cited above.

12 Gardner, p. xxii.

13 A.B. Chambers, "The Meaning of 'The Temple' in Donne's La Corona," JEGP, 59 (1960), 212.

14 Chambers, p. 217.

15 It is instructive to compare Donne's treatment of the Finding in the Temple with that of the Catholic Robert Southwell. In his "Sequence on the Virgin Mary and Christ" [The Poems of Robert Southwell, S.J., ed. James H. McDonald and Nancy P. Brown (Oxford, 1967), pp. 3-12] Southwell devotes one poem (no. xii) to "Christs Childhoode." In it, he pays homage 


\section{8 / Renaissance and Reformation}

to the paradox of wit and wisdom emanating from the youthful Jesus. But unlike Donne's Temple sonnet, Southwell makes no direct allusion to Christ's teaching in the temple as an anticipation of his prophetic role.

16 Lewalski, p. 184.

17 Gardner refers to a tradition explaining that rams lead the flock and break down what bars the way (p. 64). But Donne compares the trinity to a battering ram in "Holy Sonnet X" ("Batter my heart, three person'd God"). Here the emphasis seems to fall on Christ as the warrior-king who is called on to free the speaker's soul from the usurpation of the devil.

18 In Sermons, VIII, 241, Donne describes a torch as a "convenient Emblem of Liberality ... that wasts itselfe to enlighten others." 